\title{
A comparison of the breeding success of two strains of laboratory rats in relation to age at mating
}

\author{
P. N. Humphreys, D. Bellamy, A. Stevenson and Diana E. Lewis \\ Department of Zoology, University College, Cardiff CFI IXP, U.K.
}

Virgin females of two inbred strains of rats, a Sheffield-Wistar albino (originally derived from Boots Ltd, Nottingham) and a PVG hooded (from the colony of the Department of Zoology, Hull, established from stock of the M.R.C. Laboratories, Carshalton) were used. The strains had been bred in the same premises in Cardiff for 3 years before the experiment and environmental conditions were standardized for all the animals. Diet pellets (Modified Breeding Diet: Pilsbury) and water were freely available. Room temperature was $23-25^{\circ} \mathrm{C}$ and the artificial lighting schedule was $12 \mathrm{hr}$ light (07.00-19.00 hours) $/ 24 \mathrm{hr}$. The animals were housed at opposite ends of the room $(5.4 \times 8.1 \times 2.7$ $\mathrm{m}$ ) in mesh-bottomed cages. Females were kept with litter mates until paired; each female remained with the male until a vaginal plug was found or she was obviously pregnant and she was then returned to her litter mates for $\mathbf{1 4}$ days before being isolated in a maternity cage. Numbers of young were counted on the day after birth but litters were not handled unless several dead or dying young were seen. The animals were mated at the ages of $8,12,16$ and 20 weeks during each month of the year. There were 4-8 animals in each group and the time of appearance of vaginal plugs, size of litters and rearing success to weaning at 14 days were recorded.

The results (Table 1) show that the PVG strain performed less well at every stage than the SheffieldWistar and that although both strains showed decreased success with greater age at mating, the PVG animals deteriorated more drastically. This was particularly well marked in their relative inability to rear young to weaning even though they had smaller litters.

Table 1. The effect of age on reproductive success in two strains of rat (48-96 rats/observation)

\begin{tabular}{|c|c|c|c|c|c|c|c|c|}
\hline & \multicolumn{4}{|c|}{ Sheffield-Wistar } & \multicolumn{4}{|c|}{ PVG } \\
\hline & 8 & 12 & 16 & 20 & 8 & 12 & 16 & 20 \\
\hline $\begin{array}{l}\text { Females successfully mated }(\%) \\
\text { Females showing plugs/females }\end{array}$ & $92 \cdot 6$ & $97 \cdot 4$ & $84 \cdot 0$ & $92 \cdot 0$ & $81 \cdot 3$ & $81 \cdot 1$ & $65 \cdot 6$ & $42 \cdot 4$ \\
\hline paired $(\%)$ & $95 \cdot 0$ & $95 \cdot 1$ & $88 \cdot 2$ & $91 \cdot 6$ & $86 \cdot 1$ & $82 \cdot 2$ & $70 \cdot 7$ & $53 \cdot 3$ \\
\hline $\begin{array}{l}\text { Females giving birth } / \text { females } \\
\text { mated }(\%)\end{array}$ & $96 \cdot 4$ & 99.9 & $93 \cdot 3$ & $99 \cdot 7$ & $93 \cdot 0$ & $95 \cdot 3$ & $81 \cdot 3$ & $79 \cdot 9$ \\
\hline No. of young born/no. of females & & & & & & & & \\
\hline mated & $7 \cdot 26$ & $9 \cdot 29$ & $8 \cdot 07$ & $8 \cdot 50$ & $8 \cdot 92$ & $7 \cdot 74$ & $5 \cdot 98$ & $5 \cdot 31$ \\
\hline Young weaned/young born ( $\%)$ & $89 \cdot 1$ & $78 \cdot 6$ & $86 \cdot 4$ & $69 \cdot 3$ & $52 \cdot 0$ & $42 \cdot 4$ & $39 \cdot 3$ & $25 \cdot 2$ \\
\hline No. of young weaned/pairing & $6 \cdot 25$ & $\mathbf{7 \cdot 2 7}$ & $6 \cdot 14$ & $5 \cdot 58$ & 3.85 & $3 \cdot 02$ & $2 \cdot 23$ & $1 \cdot 16$ \\
\hline Young weaned $/$ females paired $(\%)$ & $89 \cdot 1$ & $78 \cdot 6$ & $86 \cdot 4$ & $69 \cdot 3$ & $52 \cdot 0$ & $42 \cdot 4$ & $39 \cdot 2$ & $25 \cdot 5$ \\
\hline
\end{tabular}

A seasonal rhythm was noticeable for both strains and was most marked in the weaning success of the older animals. Two maxima appeared during the spring and summer, arising indirectly from an inability to carry young through to weaning which appeared in late spring and autumn. Again, this was most exaggerated in the PVG strain (Text-fig. 1).

Early loss of fertility is well established as a feature of laboratory strains of mice (Strong \& Fuller, 1958; Fuller \& Strong, 1959; Strong, 1962; Talbert \& Krohn, 1965; Russfield, 1967). Wolfe (1943) found a decline in the number of normal ovarian follicles and an increase in atretic ones with advancing age in rats and Wolfe, Burack, Lansing \& Wright (1942) noted an age-related increase in connective tissue of the uterus and vagina. However, there are evidently strain differences indicative of a genetic relationship for low fertility and speed of age deterioration in the reproductive system. 


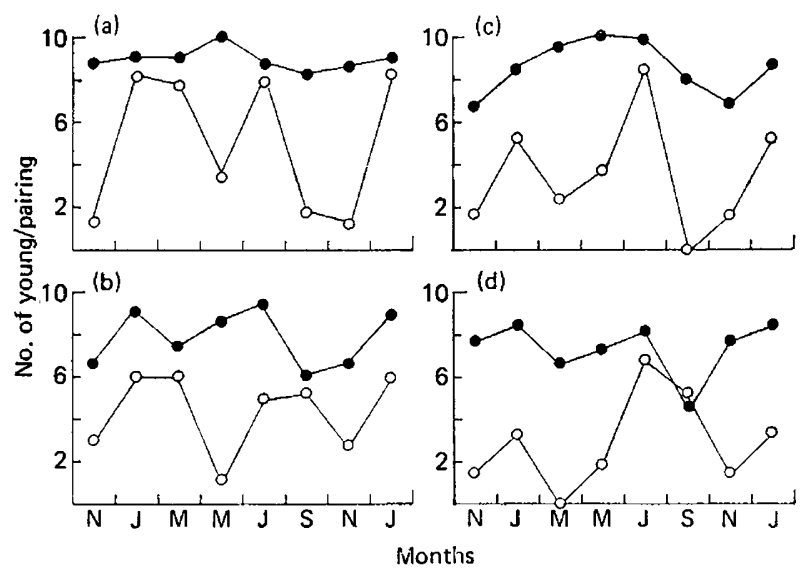

Text-fig. 1. Seasonal effects on the number of young weaned per pairing of rats (4-8/observation) of different ages (a, 8 weeks; b, 12 weeks; c, 16 weeks; d, 20 weeks) and of two strains ( $\bullet$, Sheffield-Wistar; O, PVG).

This could be important when assessing strains to produce efficient returns for the space and resources devoted to breeding. Some strains of rat appear to be more reproductively competent than either of the strains used by us. Gridgeman \& Taylor (1972), using an SPF Sprague-Dawley strain and a monogamous system of pairing, achieved an average litter size of 11 over 30 months of breeding; the only age-sensitive effect noticed was a slight alteration in the male : female ratio of the litters. This effect was not studied in our colonies, but we found strain differences in the rates of food consumption and growth and behavioural differences: these indicate the diversity of metabolism and reaction to the environment inherent in the two strains we investigated.

\section{References}

Futler, C.A. \& Strong, L.C. (1959) Maternal age selection and the fertility of mice. J. Geront. 14, 156158.

Gridgeman, N.T. \& TaYlor, J.M. (1972) Maximisation of long term productivity in a rat colony. Lab. Anim. 6, 203-206.

Russfield, A.B. (1967) Pathology of the endocrine glands, ovary and testis of rats and mice. In Pathology of Laboratory Rats and Mice, pp. 391-467. Eds E. Cotchin \& F.J.C. Roe. Blackwell, Oxford.

STRONG, L.C. (1962) Differential effects of maternal age and genetic factors on reproductive capacity of mice. In Biological Aspects of Ageing, pp. 17-25. Ed N.W. Shoch. Columbia University Press, New York.
Strong, L.C. \& Fuller, C.A. (1958) Maternal age at the time of first litters in mice. J. Geront. 13, 236-240.

TALBERT, G.B. \& KROHN, P.L. (1965) Effects of maternal age on the viability of ova and on the ability of the uterus to support pregnancy. Anat. Rec. 151, 424.

WoLFE, J.M. (1943) The effects of advancing age on the structure of the anterior hypophysis and ovaries of female rats. Am. J. Anat. 72, 361-383.

WOLFE, J.M., BURACK, E., LANSING, W. \& Wright, A.W. (1942) Effect of maternal age on the connective tissue of the uterus cervix and vagina of the rat. $A m . J$. Anat. 70, 135-157. 